\title{
Temeljne dileme o ustavni ureditvi oblikovanja vlade v Republiki Sloveniji
}

\author{
UDK: $321(497.4)(045)$ \\ Rudi Kocjančič \\ Univerza v Ljubljani, Fakulteta za upravo \\ rudi.kocjancic@fu.uni-lj.si
}

\section{IZVLEČEK}

Tudi dvajset let po sprejemu ustave so ena od temeljnih ustavnih dilem političnih elit in ustavnopravne stroke spremembe ustavne ureditve imenovanja ministrov. Pri tem sta aktualni predvsem naslednji varianti: po prvi naj bi ministre po zgledu na nemško ustavo imenoval predsednik republike na predlog v državnem zboru izvoljenega predsednika vlade, po drugi pa naj bi državni zbor volil predsednika vlade skupaj s predloženo listo kandidatov za ministre. Toda imenovanje ministrov po kanclerskem modelu, po katerem parlament sploh ne glasuje o njihovem imenovanju in tudi ne o investiturni zaupnici vladi, bi oslabilo njihovo legitimnost in preveč okrepilo ustavni položaj predsednika vlade. Po drugi strani pa bi bile volitve predsednika vlade skupaj s kandidati za ministre bolj pregledne in legitimne. Toda brez spremembe volilnega sistema, iz katerega sistemsko izhaja strankarska fragmentacija parlamenta, ne bo mogoče vzpostaviti stabilne vlade.

Ključne besede: parlamentarni sistem, kanclerski model, imenovanje ministrov, primerjalne ureditve, volilni sistem

$J E L: K O$

\section{Opustitev imenovanja ministrov v državnem zboru kot odmik od parlamentarnega sistema}

Tudi dvajset let po sprejemu ustave je še vedno aktualna dilema o spremembi ustavne ureditve o imenovanju ministrov, po kateri ministre imenuje in razrešuje državni zbor na predlog predsednika vlade (112/1. člen) in ki ni primerljiva z ustavnimi ureditvami imenovanja ministrov niti v klasičnih parlamentarnih sistemih niti $v$ nemškem parlamentarno-vladnem sistemu. Na podlagi prevladujočega mnenja, po katerem naj bi imenovanje ministrov v državnem zboru ne bilo niti konceptualno niti funkcionalno povsem v skladu s temeljnimi načeli parlamentarnega sistema, sta vlada in skupina poslancev leta 2001 vložili v ustavnorevizijski postopek predloga za spremembo ustavne

Kocjančič, R. (2012). Temeljne dileme o ustavni ureditvi oblikovanja vlade v Republiki Sloveniji. Uprava/Administration X(2), 71-78. 
Rudi Kocjančič

ureditve imenovanja ministrov, ki sta še danes v središču pozornosti politične in strokovne javnosti.

Vlada je na podlagi mnenja, po katerem naj bi bil za pripravo sprememb in dopolnitev ustavne ureditve imenovanja ministrov najprimernejši »kanclerski model«, predlagala, da bi spremenili prvi odstavek 112. člena tako, da bi se glasil: »Ministre imenuje in razrešuje predsednik republike na predlog predsednika vlade«. ${ }^{1}$

Preden se opredelimo do vladnega predloga, naj razvojno in problemsko predstavimo »kanclerski model« oblikovanja nemške vlade. Ustavna komisija Parlamentarnega sveta je namreč v osnutku Temeljnega zakona oziroma ustave predlagala, da naj bi po zgledu na klasični parlamentarni sistem, ki vključuje tudi glasovanje o investiturni zaupnici vladi, zvezni predsednik imenoval zveznega kanclerja, na njegov predlog pa zvezne ministre. Toda po kasnejših izčrpnih razpravah je parlamentarnemu svetu predlagala, da zvezni parlament na predlog zveznega predsednika izvoli zveznega kanclerja, s tem da zvezni predsednik na predlog zveznega kanclerja imenuje zvezne ministre (Hermes, 1998, str. 1209-1210.). Pri presoji ustavne komisije je namreč prevladalo mnenje, da mora Nemčija zaradi negativnih izkušenj z nestabilnimi vladami v obdobju weimarske ustave omejiti pristojnosti zveznega predsednika ter okrepiti vlogo zveznega parlamenta in vlade, predvsem pa pristojnosti zveznega kanclerja (von Beyme, 2004, str. 261).

Kot je razvidno že iz njenih različnih temeljnih modelov in tudi iz njenih dolgotrajnih razprav, je že ustavna komisija imela določene pomisleke glede sprejete ustavne ureditve o oblikovanju zvezne vlade. Tudi vidni ustavni pravniki, ki sicer poudarjajo zgodovinski in politični kontekst, v katerem je bila ustava sprejeta, ugotavljajo, da ustavna ureditev imenovanja zveznih ministrov ni združljiva s temeljnimi načeli parlamentarnega sistema. Tako Roman Herzog $v$ enem izmed prestižnih komentarjev nemške ustave označuje imenovanje zveznih ministrov na predlog zveznega predsednika brez kakršnega koli sodelovanja zveznega parlamenta kot "predrtje» (Durchbrechung) temeljnih načel parlamentarizma (gl. Herzog, 1993, 62. člen, robna opomba 76). Fritz Münch (1954, str. 159-160) komentira tak postopek imenovanja zveznih ministrov celo kot »obvod ( Abwendung) od parlamentarnega sistema. Tudi v naši strokovni literaturi lahko preberemo kritično ugotovitev, po kateri »nemški kancler oblikuje vlado v bistvu sam, pri čemer parlament ne sodeluje z nikakršnim glasovanjem, le kanclerja samega izvoli, pa še brez vlade« (Krivic, 2002, str. 281).

Vlada se v obrazložitvi svojega predloga sklicuje na »kanclersko« ureditev imenovanja zveznih ministrov, ki pa je bila, kot smo ugotovili, sprejeta v družbenem in političnem kontekstu $v$ povojni Nemčiji kot pragmatični kompromis. Pri tem podcenjuje načelo ljudske suverenosti, po katerem je v

1 Predlog za začetek postopka za spremembe ustave Republike Slovenije z osnutkom ustavnega zakona, Poročevalec Državnega zbora Republike Slovenije, št. 69/2001 z dne 6.8.2001, str. 18. 
parlamentarnem sistemu parlament izvor demokratične legitimnosti vlade, hkrati pa precenjuje pomen načela delitve oblasti v postopku oblikovanja vlade. Bistvena razlika med ustavno ureditvijo oblikovanja vlade v klasičnem parlamentarnem sistemu in $v$ nemškem parlamentarno-vladnem sistemu, kot je dosledno poimenovan $v$ nemški literaturi, je namreč $v$ tem, da klasične vlade temeljijo na investiturni zaupnici, nemška zvezna vlada pa temelji le na investituri zveznemu kanclerju (Hermes, 1998, str. 1188). Z morebitno opustitvijo imenovanja ministrov $v$ državnem zboru bi tako omejili demokratično legitimnost vlade, hkrati pa priznali predsedniku vlade »kanclerski« položaj pri njenem oblikovanju.

Ker v našem parlamentarnem sistemu ne poznamo investiturne zaupnice in ker vladni predlog ne predvideva nikakršne druge oblike glasovanja državnega zbora o podpori ministrom, bi pomenila opustitev glasovanja o imenovanju ministrov v državnem zboru odmik od parlamentarnega sistema.

\section{Primerjalni prikaz istočasnega glasovanja o volitvah predsednika vlade in o kandidatni listi za ministre $v$ parlamentu}

Po predlogu skupine poslancev, ki je bil vložen v ustavnorevizijski postopek leta 2001, naj bi sicer ohranili imenovanje ministrov v državnem zboru, toda v okviru sprememb o ustavni ureditvi oblikovanja vlade kot celote. Predlog je skupina vsebinsko oblikovala, z nekaterimi manjšimi spremembami, na podlagi strokovnega osnutka, ki sta ga pripravila Peter Jambrek in Gregor Virant leta 2000 v okviru vlade Andreja Bajuka. ${ }^{2}$

Po tem predlogu naj bi spremenili 2. odstavek 111. člena tako, da bi se glasil: »Predsednika vlade skupaj s predloženo listo kandidatov za ministre voli državni zbor z večino vseh poslancev, če ni s to ustavo drugače določeno." Glasovanje naj bi bilo javno. Državni zbor naj bi glasoval o izvolitvi predsednika vlade skupaj z listo kandidatov za ministre tudi v morebitnem drugem in tretjem krogu, s tem da bi predsednik republike po neuspešnem drugem oziroma tretjem glasovanju razpustil državni zbor in razpisal nove volitve.

Strokovna javnost je z naklonjenostjo sprejela predlog predvsem kot iskanje ustavnih možnosti za racionalnejše oblikovanje vlade, hkrati pa je bil del javnosti izrazito kritičen do osrednjega dela predloga, po katerem naj bi državni zbor glasoval o izvolitvi predsednika vlade skupaj z listo kandidatov za ministre. Po še posebej kritičnem mnenju naj bi bil predlog, po katerem naj bi državni zbor »v enem zamahu« glasoval o oblikovanju vlade, načelno in praktično nezdružljiv z oblikovanjem vlade $v$ parlamentarnem sistemu, $v$ katerem šef države v prvi fazi po različnih postopkih oblikuje vlado, v drugi

2 Predlog za začetek postopka za spremembo ustave Republike Slovenije z osnutkom ustavnega zakona, Poročevalec Državnega zbora Republike Slovenije, št. 1/2002 z dne 9. januarja 2002, str. 16. 
Rudi Kocjančič

fazi pa praviloma parlament glasuje o investiturni zaupnici vladi (prim. Krivic, 2001, str. 85-86).

Predlogje bilv primerjavis tradicionalnimi postopki oblikovanja parlamentarnih vlad res presenetljiv, toda nekatere novejše ustave so že uvedle istočasno glasovanje o oblikovanju vlade kot celote. Med temi sta tudi ustava Republike Srbije in ustava Črne gore. Tako srbska ustava določa: »Ljudska skupščina istočasno glasuje o programu in izvolitvi predsednika in članov vlade« (127/3. člen). Tudi črnogorska ustava vsebuje vsebinsko identično določbo: »Skupščina istočasno odloča o programu mandatarja in o njegovem predlogu za sestavo vlade« (103/3. člen; prim. Šuković, 2009, str. 32-33). Po obeh ustavah, kajpak logično, predlaga kandidata za predsednika vlade oziroma mandatarja predsednik republike.

Medtem ko predlog skupine poslancev izrecno predvideva javno glasovanje, srbska in črnogorska ustava ne določata načina glasovanja, tako da dopuščata javno glasovanje. Tako kot po obravnavanem predlogu je za izvolitev predsednika vlade skupaj z njenimi člani tudi po obeh ustavah potrebna večina glasov vseh poslancev. Vidni posebnosti srbske in črnogorske ustave sta predstavitev programa, pri nas po ustrezni določbi poslovnika državnega zbora (226/2. člen), in istočasno glasovanje tudi o programu vlade.

Srbska in črnogorska ustava sta tako po zgledu na nemško ustavo prevzeli volitve predsednika vlade $v$ parlamentu, hkrati pa srbski in črnogorski parlament istočasno glasujeta o izvolitvi predsednika vlade in o njeni sestavi. Aleksandar Fira (2007, str. 70-71), eden izmed eminentnih srbskih ustavnih pravnikov, je označil srbsko vlado po sedanji ustavni ureditvi kot »kanclersko vlado«. Po drugi strani državni zbor, kot vemo, v postopku oblikovanja vlade glasuje dvakrat, in sicer najprej o izvolitvi predsednika vlade, nato pa še o imenovanju ministrov.

Hkrati je treba posebej ugotoviti, da predlog skupine poslancev predvideva, da bi moral kandidat za predsednika vlade državnemu zboru v sedmih dneh posredovati predlog liste kandidatov za ministre. Srbska ustava določa, da se narodna skupščina razpusti, če se v 90 dneh od dneva njenega konstituiranja »vlada ne oblikuje« (109/3. člen), črnogorska ustava pa v postopku oblikovanja vlade ne določa rokov. Predvideni sedemdnevni rok za predložitev liste kandidatov za ministre, kot ga je predlagala skupina poslancev, je v parlamentarnem sistemu s širokimi vladnimi koalicijami, v katerem so potrebna daljša in zahtevna pogajanja o programu vlade in o njeni personalni sestavi, vsekakor prekratek.

Ustavna ureditev oblikovanja vlade, kot jo predlaga skupina poslancev in kot je določena s srbsko in črnogorsko ustavo, je za ustavnopravno stroko aktualna in izzivalna tudi v širšem sistemskem pomenu (prim. Pajvančić, 2009, str. 163-171). Slovenska ustava je namreč po nemškem zgledu poleg volitev predsednika vlade $v$ parlamentu prevzela tudi konstruktivno nezaupnico 
vladi, medtem ko sta srbska in črnogorska ustava uvedli klasično nezaupnico vladi. Vse tri ustave poznajo tudi zaupnico vladi, ki je poleg nezaupnice najpomembnejši ustavni institut za ugotavljanje politične odgovornosti vlade v parlamentarnem sistemu. Ker naj bi po predlogu skupine poslancev ohranili tudi sedanjo nezaupnico vladi, z ustreznimi redakcijskimi spremembami, se zastavlja vprašanje, ali ne bi glasovanje o izvolitvi predsednika vlade skupaj s predloženo listo kandidatov za ministre bistveno otežilo glasovanja o nezaupnici vladi. Ob tem pomisleku je treba ugotoviti, da bi bilo glasovanje o novem predsedniku vlade skupaj z listo kandidatov za ministre sicer zahtevnejše, toda hkrati bi bilo glasovanje o morebitni novi vladi kot celoti preglednejše, saj bi omogočilo tudi lažjo presojo usposobljenosti tako kandidata za predsednika vlade kot tudi kandidatov za ministre. $V$ primerjavi s sedanjo ustavno-poslovniško, deloma tudi zakonsko ureditvijo oblikovanja vlade, po kateri državni zbor dvakrat glasuje o njenem oblikovanju, in to lahko celo s podporo različnih koalicij, bi bilo glasovanje o izvolitvi predsednika vlade skupaj z listo kandidatov za ministre v državnem zboru racionalnejše, predvsem pa bolj legitimno, kot če bi po »kanclerski« metodi ministre imenoval predsednik republike na predlog predsednika vlade.

\section{Oblikovanje in delovanje vlade ter volilni sistem}

Čeprav v sedanji politični situaciji ni realnih možnosti za spremembo ustavne ureditve volilnega sistema, ne moremo mimo ugotovitve, da volilni sistem bistveno vpliva na strankarsko sestavo državnega zbora, posredno pa tudi na oblikovanje in delovanje vlade. Po slovenski ustavni ureditvi so temeljni elementi volilnega sistema sorazmerno predstavništvo, štiriodstotni volilni prag za vstop v državni zbor in odločilni vpliv volivcev na dodelitev mandatov kandidatom (80/5. člen) (Grad, 2009, str. 1728-1731). Toda tudi po določitvi višjega volilnega praga je na vseh volitvah doslej vstopilo v državni zbor sedem oziroma osem političnih strank. Hkrati ima personalizacija volitev dejansko ambivalentno funkcijo: $v$ večinskem volilnem sistemu namreč vodi v polarizacijo glasov, v proporcionalnem volilnem sistemu pa v disperzijo glasov. Uvedba personalizacije volitev v tem obsegu je bila bolj politična koncesija $v$ procesu sprejemanja ustavnega zakona kot pa možnost za sistemsko krepitev vloge volivcev na volitvah. Večjih korekcij v smeri večinskega volilnega sistema ustavni zakon ne dopušča, tako da so še naprej sorazmerno na široko odprta vrata za vstop političnih strank v državni zbor, kar posredno otežuje tudi oblikovanje vlade in slabi njeno stabilnost. ${ }^{3}$

$\checkmark$ primerjavi z našim proporcionalnim volilnim sistemom je Nemčija z zveznim zakonom o volitvah uvedla kombiniran volilni sistem, ki vsebuje prednosti tako večinskega kot tudi proporcionalnega volilnega sistema. Po omenjenem zakonu ima namreč vsak volivec dva glasova, s tem da s prvim glasom neposredno glasuje po sistemu relativne večine za svojega poslanca v volilnem okraju (5. člen), z drugim glasom pa glasuje po čistem

3 O posegu ustavnega zakona v zakonsko materijo gl. Kaučič (2007, str. 54-57). 
proporcionalnem sistemu za deželno strankarsko listo (6. člen); pri tem se izračuna število mandatov posameznih strank po številu glasov, ki so jih prejele na zvezni ravni, zaradi česar je bolj korektna oznaka, da gre za personalizirani proporcionalni volilni sistem. Pri razdelitvi mandatov se upoštevajo le stranke, ki so prejele najmanj 5 odstotkov veljavnih glasov. Takšen volilni sistem preprečuje nerazumno strankarsko razdrobljenost parlamenta ter omogoča relativno hitro oblikovanje vlade in njeno stabilnost. Tako rekoč eksotična razlika med slovenskim in nemškim parlamentom, ki izhaja predvsem iz različnih volilnih sistemov, je figurativno razvidna predvsem v tem, da je v slovenskem 90-članskem parlamentu 7 oziroma 8 strank z dvema poslancema narodnih skupnosti, v 656-članskem nemškem parlamentu pa sta praviloma dve močnejši in dve šibkejši stranki.

V Nemčiji, kjer visoka koncentracija parlamentarnih strank praviloma izhaja iz volilnega sistema, je doslej zvezni predsednik predlagal za zveznega kanclerja vodjo tiste strankarske koalicije, ki je zmagala na parlamentarnih volitvah. Z izjemo Helmuta Kohla, ki je bil zaradi hitrega razpada vladne koalicije leta 1983 izvoljen za zveznega kanclerja pri drugem glasovanju, so bili vsi drugi zvezni kanclerji v več kot šestdesetih letih izvoljeni že pri prvem glasovanju. Po drugi strani predsednik republike v Sloveniji zaradi izrazite strankarske razcepljenosti državnega zbora včasih že težko presodi, kot je bilo po nedavnih predčasnih volitvah, katere stranke bi lahko oblikovale vladno koalicijo, ki bi podprla izvolitev njegovega kandidata za predsednika vlade.

Tudi stabilnost nemške vlade ne temelji toliko na konstruktivni nezaupnici, ampak predvsem na visoki stopnji koncentracije, ki jo zagotavlja volilni sistem in sorazmerno trdna strankarska struktura parlamenta, ki ne dopušča velikega števila koalicij (Hesse, 1995, str. 150; Hofmann \& Perger, 1992, str. 240; Hermes, 1998, str. 1272; von Beyme, 2004, str. 90). Hkrati je paradoksalno, da konstruktivna nezaupnica lahko krepi tudi stabilnost neuspešnih vlad. Tako se v Sloveniji lahko zgodi, da vlada izgubi podporo v parlamentu, zaradi strankarske fragmentacije pa ni mogoče sestaviti strankarske koalicije, ki bi lahko na podlagi konstruktivne nezaupnice oblikovala novo vlado.

Torej že dvajsetletna parlamentarna praksa dokazuje, da tudi z morebitnimi spremembami ustavne ureditve vlade ne bo mogoče zagotoviti njene stabilnosti in njenega racionalnega delovanja brez spremembe volilnega sistema. Pri spremembah volilnega sistema bi bilo treba graditi na nespornih prednostih proporcionalnih in večinskih volilnih sistemov, pri čemer bi morali opustiti slabosti obeh vrst teh sistemov (Ribičič, 2001, str. 221-222). Seveda je vprašanje sprememb volilnega sistema politično vprašanje par excellence. 
Temeljne dileme o ustavni ureditvi oblikovanja vlade v Republiki Sloveniji

Prof. dr. Rudi Kocjančič je nosilec predmeta ustavno pravo na Fakulteti za upravo $\checkmark$ Ljubljani. Je tudi član več uredništev znanstvenih in strokovnih revij. $V$ letu 1991 je bil član delovne skupine za lokalno samoupravo in član delovne skupine za ustavnost in zakonitost pri Ustavni komisiji za strokovno pripravo Ustave Republike Slovenije. Je tudi podpredsednik Društva za ustavno pravo Slovenije. 
Rudi Kocjančič

\section{Literatura in viri}

- von Beyme, K. (2004). Das politische System der Bundesrepublik Deutschland, 10., aktualisierte Auflage. Wiesbaden: VS Verlag für Sozialwissenschaften GWV-Fachverlage $\mathrm{GmbH}$.

- Fira, A. (2007). Ustavno pravo Republike Srbije. Novi Sad: Fakultet za pravne i poslovne studije.

- Grad, F. (2009). Razsežnosti ustavne določitve volilnega sistema. Dnevi slovenskih pravnikov 2009, Portorož, 15.-17. oktober. Podjetje in delo 35(6-7). Ljubljana: GV založba.

- Hermes, G. (1998). V: Dreier, H. (ur.). Grundgesetz-Kommentar, Band II. Tübingen: Mohr Siebeck.

- Herzog, R. (1993). V: Maunz, T., Dürig, G. \& Herzog, R. (ur.). GrundgesetzKommentar. München: Verlag C. H. Beck.

- Hesse, K. (1995). Grundzüge des Verfassungsrechts der Bundesrepublik Deutschland. Heidelberg : C.F. Müller.

- Hofmann, G. \& Perger, W. A. (1992). Die Kontroverse. Weizsäckers Parteienkritik in der Diskussion. Frankfurt: Eichborn Verlag.

- Kaučič, I. (2007). Neposredna demokracija in volilni sistem. V: Bavcon, L. et al. (ur.). 15 let uresničevanja Ustave Republike Slovenije. Ljubljana : Pravna fakulteta.

- Krivic, M. (2001). Po desetih letih - iz ene skrajnosti v drugo? Skrajnost pri volitvah/imenovanju ministrov. VII. dnevi javnega prava, Portorož.

- Krivic, M. (2002). Formiranje vlade: drugi predlog - nestrokovna improvizacija. VIII. dnevi javnega prava, Portorož.

- Münch, F. (1954). Die Bundesregierung. Frankfurt am Main: Metzner.

- Pajvančić, M. (2009). Komentar Ustava Republike Srbije. Beograd: Fondacija Konrad Adenauer.

- Ribičič, C. (2001). Uravnoteženost političnega zastopstva v parlamentu. VII. dnevi javnega prava, Portorož. Ljubljana: Inštitut za javno upravo.

- Šuković, M. (2009). Tri različita ustavna uređenja Crne Gore. Od razbijanja šestočlane jugoslovenske federacije (1992.) do sada (2009.). Revus - Revija za evropsko ustavnost 11, 9-43. 